\title{
Local Community Perception of China Ritual Attraction as the Icon of Tourism Cultural Heritage:
}

\author{
The Case in China Village, Manado
}

\author{
Benny Irwan Towoliu*, Dimas Ero Permana, Fonny Sangari \\ Tourism Department \\ Manado State Politechnic \\ Manado, Indonesia \\ *benny.tourism@gmail.com, dimasero01@gmail.com, fonny.sangari@gmail.com
}

\begin{abstract}
Manado is the capital of North Sulawesi province, a city with a predominantly Christian community. As an area that emphasizes the spirit of kinship with its regional philosophy "we are brethren" (torang samua basudara), has had an impact on the recognition of this area as a high tolerance area of religion. The city was formerly dominated by indigenous Minahasa tribes, but over time due to its high open nature, the city was populated by various inhabitants such as Sangir, Gorontalo, Maluku and even foreign immigrants such as China and Arab migrating since the Dutch colonial era. Because this event resulted in cultural assimilation between indigenous and outsiders. Currently practically only one particular culture with religious rituals that still provide a shock value for the identity of the city of Manado. The culture is played in a region called "China Village". Amid the strong progress of the tourism industry, of course, this cultural ritual practice can be an icon for cultural tourism in the city of Manado, but whether this cultural ritual attraction can be accepted as a cultural tourism icon of Manado City. Because the dominance of indigenous people as well as other immigrants are still strong in this area. The purpose of this study is to examine the perception of local residents to the cultural ritual attractions of China as an icon of cultural heritage tourism in the city of Manado. By using field observation instruments and questionnaires distributed to 325 respondents scattered in Manado city. Empirical results show that every ritual attraction of Chinese Culture is always awaited and an interesting spectacle for the people of Manado since the people of Chinese descent domiciled in Manado City. These findings can also provide recommendations for policy makers in setting annual tourist agendas as well as providing legal certainty for this region of Chinatown with various attractions as a cultural heritage area.
\end{abstract}

Keywords-China village, Manado city, Chinatown

\section{INTRODUCTION}

According to history records in the city of Manado, since 1600 there has been one Chinese community, and in the Dutch era they were placed in a separate place called the intention of being part of the control function of the colonial government at that time. Kampung China (China Village) is name of a township in Manado City that has a special characteristic. The community is an active community but has its own character.
The village is called China Town by the Manadonese because generally it is inhabited by people of Chinese descent. The birth of the Chinese Village cannot be separated from the role carried out by the colonial government when establishing a fortress around the Manado port now. To establish a fortress, the colonial government needed artisan workers imported from various parts of the archipelago, including Chinese.

These handyman workers then formed a village joining together with Chinese merchants in the east from the location of the future fortress called China Village. Marriage between them gave birth to grandchildren and made the Chinese village more widespread and by the colonial government, "the Chinese" at the day were given the role of intermediary traders between the indigenous population (Minahasa) with the colonial government.

Furthermore, the existence of China Village became clearer, when the settlers of the settlement was carried out by the colonial government on the basis of origin, such as the Dutch Village (Kampung Belanda), Arabic Village (Kampung Arab) and Ternate Village (Kampung Ternate). In general, the Chinese live as farmers in their area of origin, but in Indonesia, on the other hand, almost throughout Indonesia, their lives are concentrated firmly in cities and towns and control of the economy in the City of Manado are in their hands.

In the development of civilization, Manado city is not separated from the role of citizens of Chinese descent who contributed to the formation of the city of Manado. Basically Chinese citizens get along very well with the native people. However, until now in the running traditions of their faith, they still maintain their original ways. Until now there are certain traditions such endangered Chinese martial arts (Kung Fu).

Currently Manado has become a marine tourism destination, and this attracts the Chinese tourists to visit the city of Manado, because basically they love sea tourism. Linked to tourism and tourism product diversity, the product of cultural ritual attraction that has been assimilated with local culture can be an opportunity for the presence of a new destination attraction as a major supporter of marine tourism in Manado City. The main reason is that only their cultural attractions that have shocked the values and are still well preserved in 
Manado, but do local people agree to make Chinese ritual attraction as the icon of cultural tourism? The purpose of this study is to analyze local people's perception of china ritual attraction as the icon of tourism heritage in Manado.

\section{LITERATURE STUDY}

Tourism is the activity of traveling by persons from a place of origin with no intention to stay or work to the destination, and only temporary to spend leasure time $[1,2]$.

Tourism can also be distinguished by the motives of tourists in visiting a place. The motives are: culture, maritime, nature reserve, convention, agro, hunting and pilgrimage [3]. While Spillane mentioned the motives of the trip such as leasure travel, recreation, culture, sports, business affairs and convention activities [4]. From these motives the region can develop objects and attractions based on the potential of its potential and the power of Indonesia exists in the diverse nature and culture.

So far, the focus of tourism development in Indonesia is only on natural attractions (nature-based attraction) while having a wide range of tribes and cultures, which can be preserved and managed to provide added value for the welfare of the community. In the context of socio-cultural categories of tourism attractions are included in the attraction / heritage / culture (heritage / culture tourism) associated between tourism and heritage [5]. In the Indonesian heritage conservation charter heritage was agreed as an heirloom [6]. Heritage (Pusaka) Indonesia includes: natural heritage, cultural heritage, and landscape heritage that is a combination of nature and cultural heritage in the unity of space and time. Landscape heirloom is known by a new understanding of cultural landscape which focuses on the interrelation of culture and nature. It is a complex phenomenon with a tangible and intangible identities. Holding on to the above understanding, folklor in the form of folklore, dance, culinary, traditional music, and others entered in a cultural heritage called heritage.

Discussion about tourism needs to be seen from the perception of tourists in measuring whether the attractiveness of tourism is interesting or not [7], especially the tourism heritage tourism [8], analyzed the perception on tourists to heritage tourism by showing that the tourists are very satisfied with culture and authenticity of relics of the Han Dynasty, but there are concerns from tourists about the disappearance of local cultural authenticity. Others forms of disappointment are business arrangements, inadequate tourism facilities, poor service, and limited tourism programs, while Irandu sees the importance of the role of tourists in conservation of cultural tourism [9]. Kristiningrum, sees a mixture of cultures (multi ethnic) in Malaysia has created a multi-ethnic market, a visible form of the art market being used as heritage tourism and creative tourism [10]. It has attracted both local and foreign tourists to visit the location.

In the development of heritage tourism more specifically religious tourism (pilgrim tourism) [11], look more at the model of management that put forward the carrying capacity, the reason in heritage tourism especially pilgrim (pilgrimage tour) emotional problems usually more strongly affect people to visit religious sites, and to maintain the sustainability of religious sites, it is necessary to consider the carrying capacity of tourism management. Poilios and Cannas see the management of cultural heritage sites remain on sustainable conservation management only in management organizations that need synergy between the combination of private and public management $[12,13]$. The basic consideration is that the site is located close to the community settlements even though the site has entered the private area. The management of heritage tourism by Cadar, Yulong and Svensson remain on the conservation and sustainable tourism arrangements, but the synergy between higher education, community and tourism sector is needed [14-16].

If management of heritage sites serve as a tourist attraction without a soul, the heritage tours will not attract tourists to visit the site. Rudana explains that in the soul rather than on cultural and archaeological sites as a tourist attraction [17]. Cases of archaeological and cultural sites in Bali provide valuable lessons in which human interaction from ancient sites comes alive when local people interact with ancient objects so that they are considered alive and give meaning. The interaction is in the form of religious ceremonies held in the locations of ancient places.

From some previous writings it can be concluded that the management of heritage tourism is successful when: (1) concerning conservation and sustainability, (2) the importance of synergy between heritage owner, local community, education and government (regulation) in managing historical heritage and (3) ancient cultural sites will be preserved when religious attractions or rituals are performed at these locations to give meaning to every historical legacy.

Involvement of local communities, in fact, is really needed in the management of cultural tourism.

Until the year 2010, it is estimated there were only 46 historic sites found in Manado City, with only two historical sites that still provide a surprise value for visitors to visit, namely the Ban Hin Kiong Temple (Kwan Kong Temple) and old church of Centrum Manado while the other 44 sites are not interested [18]. How is the response of the local community when the Chinese cultural rituals are used as a cultural heritage tourism icon? The practical cause of the indigenous culture of Manado is a pluralist city.

\section{METHODS}

The study was conducted in the city of Manado from December 2017 to June 2018. The respondents were the local people of Manado. Questionnaires were designed by asking their perceptions of the attractions of Chinese culture rituals as the icon of cultural heritage tourism of Manado. Questionnaires have been developed and tested on as many as 30 tourism students at the end of December 2017. Basically, the results of the trial showed no major problems, there were only certain sentences with a need to make word changes. In January 2018 a survey of 350 respondents was conducted, using sampling method and accidental sampling. Questionnaires were designed using an attitude scale that is a Likert Scale with choices: $1=$ "strongly disagree", 2 = "disagree", 3 "quite agree", 4 = "agree", 5= "strongly agree". In early June questionnaire collected as many as 325 questionnaires were collected, 25 
questionnaires were not answered completely, and were considered to be damaged.

\section{RESULTS AND DISCUSSION}

Table I summarizes the demographic profiles of respondents who meet the requirements. In the table there are 325 respondents with gender distribution: 54.5 percent male and 45.5 percent female. Most of the respondents are in the age group 31 to 40 (45, 8 percent): aged 20 to 30 (25.5 percent): aged 41 to 50 (16.9 percent) and the aged over 51 years (11.7 percent). And the level of education is dominated by respondents with high school education level. The most dominant jobs are private industries (34.8 percent), while the other types of work tend to be evenly distributed. With the characteristics of these respondents, it can be concluded that the respondents were distributed fairly evenly.

TABLE I. DEMOGRAPHIC PROFILE OF RESPONDEN

\begin{tabular}{|l|l|l|l|}
\hline Respondent & \multicolumn{1}{|c|}{ Variable (n= 325) } & Number & Percent \\
\hline \multirow{4}{*}{ Gender } & Male & 177 & 54,5 \\
\cline { 2 - 4 } & Female & 148 & 45,5 \\
\hline \multirow{4}{*}{ Education } & $20-30$ & 83 & 25,5 \\
\cline { 2 - 4 } & $31-40$ & 155 & 45,8 \\
\cline { 2 - 4 } & $41-50$ & 55 & 16,9 \\
\cline { 2 - 4 } & $>51$ & 38 & 11,7 \\
\hline \multirow{5}{*}{ Occupation } & Middle School & 4 & 1,2 \\
\cline { 2 - 4 } & High School & 221 & 68,0 \\
\cline { 2 - 4 } & Bachelor & 100 & 30,8 \\
\hline & Government & 71 & 21,8 \\
\cline { 2 - 4 } & Employee/Military/Police & 113 & 34,8 \\
\cline { 2 - 4 } & Private Employee & 20 & 6,2 \\
\cline { 2 - 4 } & Employees of State-Owned & 20,9 \\
\cline { 2 - 4 } & Enterprises & 37 & 11,4 \\
\cline { 2 - 4 } & Professional Worker & 13 & 4,0 \\
\cline { 2 - 4 } & Student & 51 & 15,7 \\
\cline { 2 - 4 } & Handyman & 4 & 0,9 \\
\cline { 2 - 4 } & Loborer & 13 & 4,0 \\
\cline { 2 - 4 } & Housewife & & \\
\hline
\end{tabular}

In table 2, the respondent's responses to the ten indicators about the ritual attractions of Chinese descendants when used as icons of heritage culture. The following indicators are asked: (1) The descendants maintain the ancestral cultural rituals, (2) Ritual toa pe kong have been long-maintained attractions in the city of Manado, (3) Attractions ritual toa pe kong become characteristic of chinese culture in Manado city, (4) This cultural ritual attraction can represent an old culture that is still preserved, (5) The ritual attractions of the descendants are interesting to watch, (6) Acts of old chinese culture deserve to be an icon of cultural tourism, (7) Local people generally like Chinese cultural attractions, (8) Cultural ritual attractions should be maintained and protected by local regulations, (9) Chinese cultural attractions have surprising and exciting values tn watch, and (10) Area of china town with various cultural attributes / cultural ornaments deserve to be a cultural heritage.

Indeed, there is one Chinese culture that is very popular with people who still preserve and become a spectacle that has been interesting since the arrival of the Chinese people to the city of Manado. Cultural traction that has become an attraction for residents and tourists ever since Cap Go Meh. Cap Go Meh is a Chinese cultural festival that symbolizes the 15th and final day of Chinese New Year celebrations for Chinese communities around the world. This term comes from the Hokkien dialect and literally means the fifteenth day of the first month $($ Cap $=$ Ten, Go $=$ Five, Meh $=$ Night $)$. This means, the period of Chinese New Year celebrations lasts for fifteen days.

TABLE II. LOCAL COMMUNITY PERCEPTION OF CHINA RITUAL ATTRACTION AS THE ICON OF TOURISM CULTURAL HERITAGE

\begin{tabular}{|c|c|c|c|}
\hline No & Indicator & Mean & Sd \\
\hline 1 & $\begin{array}{l}\text { The descendants maintain the } \\
\text { ancestral cultural rituals }\end{array}$ & 4,6185 & 0,48651 \\
\hline 2 & $\begin{array}{l}\text { Ritual toa pe kong long- } \\
\text { maintained attractions in the city } \\
\text { of Manado }\end{array}$ & 4,2677 & 0,62289 \\
\hline 3 & $\begin{array}{l}\text { Attractions ritual toa pe kong } \\
\text { become characteristic of china } \\
\text { culture in Manado city }\end{array}$ & 4,1138 & 0,63535 \\
\hline 4 & $\begin{array}{l}\text { This cultural ritual attraction can } \\
\text { represent an old culture that is still } \\
\text { preserved }\end{array}$ & 3,7877 & 0,80191 \\
\hline 5 & $\begin{array}{l}\text { The ritual attractions of the } \\
\text { descendants are interesting to } \\
\text { watch }\end{array}$ & 4,5908 & 0,49245 \\
\hline 6 & $\begin{array}{l}\text { Acts of old chinese culture } \\
\text { deserve to be an icon of cultural } \\
\text { tourism }\end{array}$ & 3,5231 & 0,79945 \\
\hline 7 & $\begin{array}{lll}\text { Local people generally } & \text { like } \\
\text { Chinese cultural attractions } & \end{array}$ & 3,4338 & 0,47890 \\
\hline 8 & $\begin{array}{l}\text { Cultural ritual attractions should } \\
\text { be maintained and protected by } \\
\text { local regulations }\end{array}$ & 4,3538 & 0,47890 \\
\hline 9 & $\begin{array}{l}\text { Chinese cultural attractions have } \\
\text { surprising and exciting values on } \\
\text { watch }\end{array}$ & 4,3938 & 0,48935 \\
\hline 10 & $\begin{array}{l}\text { Area of china with various } \\
\text { cultural attributes / cultural } \\
\text { ornaments deserve to be a cultural } \\
\text { heritage }\end{array}$ & 3,6185 & 1,07251 \\
\hline
\end{tabular}

Attractions have become a spectacle of local residents, because there are attractions called 'lokthung' or 'thangsin' where there is someone who is an intermediary medium that is said to have been read by certain mantras believed to have been possessed by the spirit of the god to give blessings to his people. They will usually do some attractions such as tongue slicing, cutting arms or piercing parts of their bodies with slashes of swords, machetes, etc, the local community of Manado called "Enci Pia"; or in Pontinak and Singkawang called "Tatung". The attraction has become a calendar of tourism event in Manado.

As shown in table 2, respondents generally see the indicators quite agree and agree. Indeed, the respondents gave different values for each indicator of the questions submitted. In the first indicator the researcher explores the knowledge and understanding of the respondent; according to the respondents, the descendants still preserve the cultural traditions of their ancestors. The average respondents agree answers 4,6185 percent, meaning it is true, that they still maintain tradition. This shows that descendants are still loyal to their ancestral culture. Indeed, their ancestral culture is very close to their belief or religion, Budha. The average respondents answer agree which means they still maintain tradition. This shows that descendants are still loyal to their ancestral culture. Indeed, their ancestral culture is very close to their belief or religion, 
konfuchu. Indeed, when cultural traditions are associated with the religious life of a particular community, there is a tendency that the tradition will be well maintained. Balinese society is a real example where their cultural traditions are still maintained, even the culture has become a tourism product that is sold well [19]. sThis applies also to the community of Chinese descendants who live in the area of the village of China Manado, who still maintain their traditions because they relate to trust, although they also experience acculturation with local culture.

In the second and third questions the researcher explores the understanding of the local people about an old attraction that is often done by the Chinese descendants, called Toa Pe kong. This attraction shows someone being an intermediary medium. This attraction is interesting as it shows the person possessed by the god is spirit performing attractions such as slicing the tongue, cutting off the arm or stabbing the body with a sword or machete. The average respondents answered agree with a percentage of 4.2 . This tradition is already very well known among the local community, and has been preserved since the Chinese people entered the city of Manado. It is very reasonable to be known by the locals because it is celebrated every year.

In the third question, the researchers asked whether the attraction has represented an old culture that is preserved in the lives of Chinese descendants. Answers from respondents on the average were somewhat agree, namely 3.7 percent. Further exploration is interesting, because respondents are local people who have long interacted with descendants so they know very well that in the midst of a tradition of descent, there are not only Toa Pe Kong attractions that are still preserved, there are also other ones. The attraction was very exciting because it relates to the Chinese New Year calendar.

The fifth question asked was whether their interesting ritual attractions were watched? the average respondents answered agree, ( 4.5 percent). In the study, the respondents have been brought by a long experience handed down by ancestors of local communities, where the descents of have become an interesting spectacle since they entered the city of Manado. Besides the spectacle is also a free entertainment for local people. So this attraction has become a hereditary spectacle.

On the sixth question, the researchers asked whether the old Chinese cultural attractions deserve to be an icon of cultural tourism. the answer from the average respondent is somewhat agree, which is 3.5 percent. Because it is understood that the local community in Manado City is still have a lot of cultural attractions that are still well preserved, only they have not been exposed. Chinese cultural attractions are preserved, because the cultural attractions are parts of their ritual of belief.

The seventh question is whether local people generally like the attractions of Chinese culture. The average respondents answered was somewhat agree, which was 3.4 percent. From the observations of the researchers, the average person who often watch Chinese cultural attractions such as Cap Go Meh or Toa Pe kong (1) local people from around the village of China in Manado, (2) People from old villages around Manado city and (3) Local people who have middle to lower economic income. So people who come from luxury housing areas and have middle to upper economic income are rarely found. Even if they still can be found, they are generally descendants who are no longer diverse in kong fu chu, as well as part of the family that celebrates the Chinese New Year celebration.

The eighth question is about the attractions of Chinese culture rituals that must be maintained and protected by regional regulations. This question is raised because there is a connection between cultural ritual attractions and various cultural historical buildings that are still preserved [17] Mentions that a historic heritage site will come alive or appear soulful when human activities interact in it. A historic heritage site will come alive or appear soulful when human activities interact in it. This is evident from the results of an inventory of historical heritage sites found in the city of Manado, totaling 46 to sites, only 2 historical sites are of interest for tourists to visit, namely Ban Hin Kiong Temple located in the village of China which is a place of worship for descendants of Kong $\mathrm{Hu}$ Chu and the Centrum Church a place of worship of Christian Protestants. Both places are in great demand by visitors because they still give a surprise [8].

Many historical heritage sites in various places in Indonesia have been damaged by nature or even by humans or even switched to other forms. This also happened in the city of Manado and its surroundings. Many old buildings from the Dutch colonial era seemed lost and even changed their faces to other new buildings. Manado's old city area began to lose its colonial-faced buildings, along with the loss of the existence of a colonial-faced historical building that was able to form the values of locality in an architectural form for the city of Manado. From this case the researcher explored the answer to the eighth question that the attraction of the ritual of Chinese culture must be maintained and protected by regional regulations. Answers show that the average respondent answered agree, 4.5 percent. It also illustrates that respondents want the area of the village of China Manado to be used as an area protected by regional regulations, where all heritage sites both tangible and intangible are protected and preserved.

To the ninth question: the attractions of Chinese culture have a surprising and interesting value to watch. The average respondents answered agree, which was 4.39 percent. The results of the study of the respondents showed that the value of ritual attractions displayed as in the Toa Pe Kong attraction by displaying someone possessed by the spirits of the gods by taking action to slash the tongue and pierce the body with a sword or machete; the attraction is still original and not a fake attraction. There are other interesting things from the observations of researchers about why this ritual attraction is always awaited by local people, it turns out that this attraction is not always present in annual festivals in Chinese New Year celebrations. This ritual attraction must first be prayed for, and requested approval from the gods, whether the gods agree to be displayed. That what makes the surprise value of this attraction. By looking at cases in tourist areas in Bali, where at the request of tourists, a particular ritual or dance attraction ritual that is sacred is easily displayed for the sake of commodities. The need for attraction of the Chinese cultural ritual is protected not only by the meaning of the name, but also by being protected from displaying like merchandise. So that the value of 
uniqueness and surprise is maintained and in demand by local people and tourists.

To the tenth question, is the village of china region with various cultural attributes worthy of being a cultural heritage, the respondents' answers, on the average, were somewhat agree, that is 3.6 percent. Respondents expect not only for the Chinese village area, but for all historical heritage sites that have authentic value in Manado City. They need to be designated as a cultural heritage building, and managed properly, so that no function changes or damage occurs. Specifically, for the China region, respondents hoped that the area would be arranged like a Chinese village by returning its original identity according to the name of the area. Indeed, in several places in other countries the village of China always displays its face as its name Chinatown.

Perception assessment in total shows the average respondents answered agree, that is 4.06985 percent. This will give implication in the form of Manado local support for the efforts of a sustainable cultural area as a tourist area that can be an alternative tourism, in addition to marine tourism. In addition, the local community also supports the Kampong China area with various cultural sites as an icon of cultural heritage tourism. The main thing that gets the support of the local community is the need for local regulations to protect the area as a cultural area. The next support is the realignment of the area according to its name. This support can strengthen local governments in building the region as a tourism area. Identity that refers to the identity of the region needs to be revived.

Identity refers to the identity of the Chinese Village communities, and Manado as a colonial heritage city. Chinese villages are part of the city of Manado and perhaps in the next generation remains only name, when the government does not seriously pay attention to the expectations of local people who live in association with the community of Chinese descendants. The Manado city government needs to organize this Chinatown as a special characteristic location.

Descendants living in the area are able to work together to build around the location. This form of arrangement is done by creating a Chinatown location to become a major or alternative tourist location, depending on how the Manado city tourism development strategy plans. The government through the tourism office must be able to create an icon of cultural tourism, where tourists visiting the cities of Manado and Bunaken are incomplete if they do not enjoy the village of Manado, China town as an old village that still exists in Manado.

The need for structuring the completeness of tourist accessories such as the name of the characters and the street name of the Chinatown area using Chinese calligraphy with a translation in Indonesian. In every shop house and residence, Chinese accessories are provided to give a different impression from other settlements. Other convenience needs to be facilitated, such as not allowing public transport cars to cross this tourist pilot area, parking outside the area, good security systems, cleanliness, and the availability of various needs as the main transport tool. For this area only horse carriages called "Bendi" are permitted by the local community. Bendi transport equipment is very close to people's lives in the past Manado Chinatown. Then for special days the barongsai - kung fu attraction is turned on. The ceremonial tradition which is part of the Chinese New Year (Lunar New Year), namely Toa Pekong, is retained and not modified or commodified for the benefit of tourists, meaning that the sacredness of the event is maintained. Especially for culinary the need for Chinese cuisine is provided. The point is that the city government rearranges this Chinatown area similar to the atmosphere of China, Hong Kong or Macau and besides, the local Minahasa-Chinese wisdom needs to be maintained. The point is the Chinatown area was created a kind of diorama or small living museum, depicting the history of the Chinese people 's first journey to Manado, including past photo locations, and a variety of creative economic crafts "signs" to be used as souvenirs.

\section{CONCLUSION}

This research is an initial investigation, namely the perception of local people in assessing the attractions of Chinese cultural rituals to be used as an icon of heritage cultural tourism. Empirical findings show that generally the local community agree when the attraction of the Chinese culture ritual is used as a cultural tour. Regardless of the limited scope of the data collection period and the small number of respondents and indicators, the findings of this study could provide useful insights for the local government in determining the Chinese region with its cultural ritual attributes as a protected and well-managed cultural area for the benefit of tourism. Other business actors such as travel businesses can design tour packages which include cultural tours of the old village of China in the city of Manado. The approach used in this study places limits on its ability to make broad conclusions. Indeed, the study respondents did represent a number of local communities in the city of Manado. But for other research in the future, this research can be repeated by adding a wider indicator. In addition, research was also conducted on descendants to see how their answers were when cultural rituals and their neighborhoods were used as icons of cultural tourism.

\section{ACKNOWLEDGMENT}

The authors regard to the Ministry of Research, Technology and Education via Research Institution in State Polytechnic of Manado which funded this research.

\section{REFERENCES}

[1] Mc Intosch and S. Gupta, "Tourism, Principles, Practices, Philosophies, Third Edition," Grid Publishing Inc. Ohio, 1980

[2] M. Ben, Sarbini, Paradigma baru pariwisata, sebuah kajian filsafat. Yogyakarta: Kaukaba, Cetakan Kedua, 2010.

[3] N.S. Pendit, Ilmu Pariwisata sebuah pengantar perdana. Jakarta: Pradnya, Paramita, 1994.

[4] J.J. Spillane, Pariwisata Indonesia Sejarah dan Prospeknya. Yogyakarta: Kanisius, 1987.

[5] W. Nuryanti, "Heritage and postmodern tourism", Annals of tourism research, vol. 23 , no. 2 , pp. 249-260, 1996 
[6] Anonim, Piagam Pelestarian Pusaka Indonesia- dikelola oleh Jaringan Pelestarian Pusaka Indonesia dan International Council on Monuments and Sites (ICOMOS) Indonesia didukung oleh Kementerian Kebudayaan dan Pariwisata RI, 2003

[7] Towoliu, I. Benny and E. Mita, Takaendengan, "Perception of Tourist towards the Potential Development of Tumpa Mountain Area as Integrated Ecotourism, Manado, North Sulawesi Province" Journal of Indonesian Tourism and Development Studies vol.3 ,no. 1, pp. 1-10, 2015.

[8] B.I. Towoliu, "Konservasi vs Pariwisata; Problem dan tantangan kasus situs bersejarah di Manado Propinsi Sulawesi utara," Jurnal Ekowista, Ed 17th,ProgrmStudy Ekowisata Bawah Laut, Politeknik Negeri Manado, Indonesia, pp. 7-16, 2012.

[9] Irandu and M. Evaristus, "The role of tourism in the conservation of cultural heritage in Kenya," Asia Pacific journal of tourism research, vol. 9, no. 2, 133-150, 2014

[10] N.D. Kristiningrum, "Heritage tourism dan creative tourism: eksistens pasar seni (central market) di malaysia sebagai salah satu pasar bersejarah," Jurnal Hubungan International, vol. 7, no. 1, pp. 43-54, 2014

[11] S. Khreis, "Evaluation of usage and management of pilgrimage sites in Israel and Jordan: a comparative study", Almatourism: Journal of Tourism, Culture and Territorial Development, vol. 6, no. 12, pp. 176192, 2015.
[12] I. Poulios, "Discussing strategy in heritage conservation: living heritage approach as an example of strategic innovation," Journal of Cultural Heritage Management and Sustainable Development, vol. 4, no. 1, pp. 16-34, 2014.

[13] R. Cannas, "The Sustainable Tourism Management of Cultural Heritage: the Case of the Rosas Mine in Sardinia", Almatourism-Journal of Tourism, Culture and Territorial Development, vol. 7, no. 14, 38-59, 2016.

[14] S. Cadar, "New Skills in a Changing World: Strategic Alliances at World Heritage Sites", Almatourism-Journal of Tourism, Culture and Territorial Development, vol. 5, no. 2, pp. 12-19, 2014

[15] Li, Yulong, and H. Caroline, "Community involvement for sustainable heritage tourism: a conceptual model", Journal of Cultural Heritage Management and Sustainable Development, vol. 5, no. 3, pp. 248-262, 2015.

[16] E. Svensson, "Heritage and development outside the metropolis: Discussing issues of attractiveness, growth, participation and sustainable development", Journal of Cultural Heritage Management and Sustainable Development, vol. 5, no. 1, pp. 4-13, 2015.

[17] S.P. Rudana, Menuju Visi Sempurna, Seni Budaya Sebagai Jiwa Bangsa. Yayasan Seni Rudana, 2009.

[18] T.A. Megumi, Penyusunan Kajian Potensi Pariwisata \& Kebudayaan Kota Manado. Laporan Akhir, 2010.

[19] M. Picard, Bali: Pariwisata budaya dan budaya pariwisata. Kepustakaan Populer Gramedia, 2006 